\title{
Synthesis and performance assessment of coconut fiber solid adsorbent for waste cooking oil purification as biodiesel feedstock
}

\author{
Rama Oktavian*, Bambang Poerwadi, Mochamad Reza Pahleva, Mochammad Wahyu \\ Muharyanto, Supriyono
}

Chemical Engineering Department, Brawijaya University, Jalan Mayjen. Haryono 167, Malang, 65145 Indonesia

* Corresponding author: rama.oktavian@ub.ac.id

\section{Article history}

Received 8 May 2019

Revised 14 August 2019

Accepted 20 November 2019

Published Online 15 June 2020

\begin{abstract}
Waste cooking oil can be considered as an alternative biodiesel feedstock for replacing edible oils. However, this feedstock can not be directly used since it contains much impurities and high Free Fatty Acid (FFA) content. Thus, pre-treatment process is required to enhance the feedstock quality. Adsorption using activated carbon is one of various methods that can be applied to reduce FFA content which is relatively easy and cheap. Coconut fiber is biomass waste that can be utilized in activated carbon production. This work has successfully synthesized activated carbon from coconut fiber with activator medium of $\mathrm{H}_{3} \mathrm{PO}_{4} 10 \%$ weight and carbonization temperature of $600{ }^{\circ} \mathrm{C}$, indicated from yield, water content, ash content, and methylene blue adsorption capacity. The yield of carbonization process developed in this work reached $40 \%$ while the yield for water content, ash content, and methylene blue adsorption capacity were $2.5 \%, 2.3 \%$ and $1646.1 \mathrm{mg} / \mathrm{g}$ carbon, respectively which complied with SNI 06-3730-1995. This adsorbent was tested on fixed bed adsorption column with FFA reduction reached up to $93 \%$ at waste cooking oil flowrate of $3 \mathrm{ml} / \mathrm{min}$ for 45 minutes operation time.
\end{abstract}

Keywords: Activated carbon, adsorption, coconut fiber, waste cooking oil

\section{INTRODUCTION}

Biodiesel has been gaining a tremendous attention as a promising alternative energy for replacing fossil fuel and optimizing renewable energy utilization in Indonesia, as requested by government policy due to its beneficial properties such as low sulphur content, lack of aromatics, higher lubricity and very high cetane number. Vegetable oil is comprised $95 \%$ of biodiesel feedstock (Sanjid et al., 2016). This will give impacts on biodiesel price and food feedstock competition problem (Sanjid et al., 2014), resulting in the increase in the proportion of operational cost in biodiesel production process up to reach $75-90 \%$ (Bonassa et al., 2016). Thus, finding an alternative feedstock for biodiesel production will solve problems encountered by vegetable oil. Non-edible oil can be considered as an alternative biodiesel feedstock since it can decrease operating cost until 60\% (Marchetti, et al., 2008), which can enhance the economic viability of biodiesel production.

Waste cooking oil has a considerable potential to be converted into an environmentally friendly biodiesel which can overcome the problematic waste. However, during frying process, vegetable oil can undergo various chemical reactions such as polymerization, hydrolysis and oxidation (Ullah, et al., 2015). Those reactions will cause decomposition of triglyceride into other compounds such as free fatty acids (Canakçi \& Ozsezen, 2010). It can degrade the quality of oil, making it to be impractical to convert it directly into biodiesel due to its high content of fatty acid (up to 15\%) and impurities (Knothe, et al., 2010), which can be considered as persistent organic pollutants which are responsible for various lethal diseases and environmental problems (Alharbi, et al., 2018).

Adsorption process is one of favorable processes that can be employed for impurities removal due to its simplicity, costeffectiveness and its efficiency (Saleh and Gupta, 2014). This process has been widely used in removal of hazardous dyes in aqueous solution to improve the quality of water. Mittal, et al. (2010) utilized bottom ash in removing and recovering Chrysoidine $\mathrm{Y}$ from aqueous solution. The Chemical Oxygen Demand (COD) of water was successfully decreased using adsorption process with $\mathrm{TiO}_{2}$ solid adsorbent as catalyst (Gupta, et al. 2011) and it was redeveloped by combining $\mathrm{TiO}_{2}$ with multiwalled carbon nanotubes as composite solid adsorbent to degrade methyl orange (Saleh and Gupta, 2012). This carbon nanotube was successfully used as a super selectivity sensor for monitoring of mercury ion(II) in water before it was employed as composite solid adsorbent (Khani, et al., 2010).

The development of solid adsorbent for waste treatment especially for dye removal has been made. Some researchers successfully developed metal oxide-based solid adsorbent coupled with photocatalytic activity for dye removal (Saravanan, et al., 2014a; Saravanan, et al., 2014b; Ali, et al., 2017; Khan, et al., 2017; Saravanan, et al., 2016a; Saravanan, et al., 2016b; Saravanan, et al., 2015a; Devaraj, et al., 2016; Saleh and Gupta, 2011; Ghaedi, et al., 2015 Saravanan, et al., 2015b; Saravanan, et al., 2013a; Saravanan, et al., 2013b; Saravanan, et al., 2013c; Saravanan, et al., 2013d; Saravanan, et al., 2013e; Saravanan, et al., 2013f;).

Besides metal oxide-based adsorbent, carbon-based adsorbent has been gaining tremendous attention for waste treatment application due to its low-cost and wide application (Ahamruzzaman and Gupta, 2011; Mohammadi, et al., 2011; Gupta and Saleh, 2013; Gupta, et al., 2014; Asfaram, et al., 2015). Activated carbon has been receiving its popularity among other adsorbent materials. It is commonly used for adsorption process (Rashidi, et al., 2013).

Activated carbon can be synthesized easily from biomass (Rashidi and Yusup, 2015) for example sugarcane bagasse (Seixas, et al., 2017), waste materials (Gupta, et al., 2014; Gupta, et al., 2013) and coconut 
fiber. Coconut fiber can be considered as an appropriate feedstock for activated carbon production since it contains $64 \%$ of cellulose and $22 \%$ of lignin (Phan et al., 2006). High content of cellulose makes it possible to be synthesized as solid adsorbent (Suhas et al., 2016). Activated carbon from coconut fiber can reduce FFA content of waste cooking oil in batch process. Adsorption process using solid adsorbent (combination of activated carbon and silica) was tested and it reduced FFA content up to $39 \%$ (Sonkaew \& Chaisena, 2012). To the best of our knowledge, some previous researches only focused on batch process. Very few research on continuous adsorption process have been performed. This study was focused on solid adsorbent synthesis and continuous adsorption process of waste cooking oil to reduce FFA content, which can be used as reference for biodiesel industry, especially in pre-treatment of biodiesel feedstock.

\section{EXPERIMENTAL}

\section{Materials}

Coconut fiber as primary material for solid adsorbent synthesis in this study was supplied by local supplier of carpet-home industry in Malang, Indonesia. This material was pre-treated to reduce its moisture content. Waste-cooking oil was supplied by local food-home industry in Malang, Indonesia with FFA content of less than $5 \% \mathrm{H}_{3} \mathrm{PO}_{4}$ for adsorbent activation process was purchased from Sigma Aldrich analysis grade. $\mathrm{NaOH}$ for FFA content measurement was purchased from Sigma Aldrich with pro analysis grade of $99 \%$ purity.

\section{Apparatus}

Apparatus used in this study consists of activated carbon solid adsorbent synthesis apparatus and adsorption column, as shown by Fig. 1 and 2, respectively. Activated carbon solid adsorbent synthesis apparatus consists of furnace 'carbolite' and stainless steel carbonization reactor with dimension of length: $13 \mathrm{~cm}$, width: $15 \mathrm{~cm}$, and height: $13 \mathrm{~cm}$, as depicted in Fig. 1. While adsorption column was made from acrylic with dimension of ID: $2.5 \mathrm{~cm}$ and height: $48 \mathrm{~cm}$, as shown in Fig. 2.

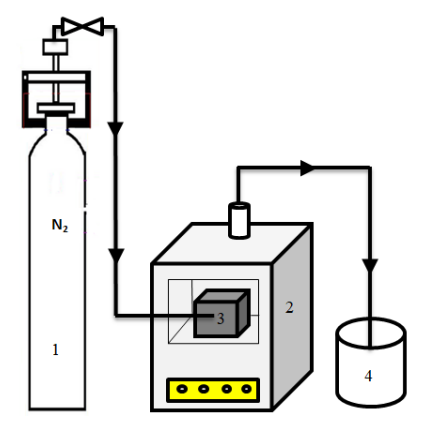

1. Nitrogen gas cylinder

2. Furnace

3. Carbonization reactor

4. Nitrogen gas trap

Fig. 1 Activated carbon solid adsorbent synthesis apparatus

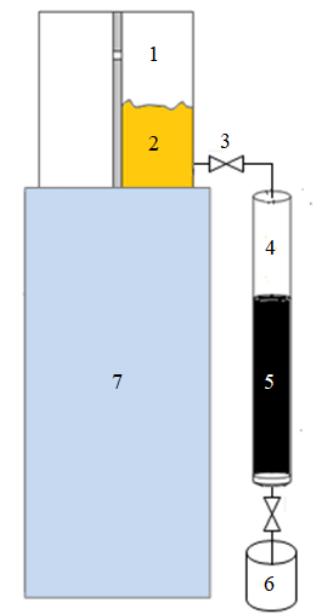

1. Oil reservoir

2. Waste cooking oil

3. Valve

4. Adsorption column

5. Activated carbon

6. Oil trap

7. Oil reservoir deck

Fig. 2 Continuous adsorption column apparatus.

\section{Synthesis of activated carbon}

Coconut fiber was fed into carbonization reactor inserted furnace at temperature of $600{ }^{\circ} \mathrm{C}$ for 1 hour. It was then cooled until it reached room temperature. There was nitrogen gas flow in continuous flow rate to remove oxygen in reactor. This process was called carbonization process.

After carbonization process, carbon was formed. It was then immersed and activated with $\mathrm{H}_{3} \mathrm{PO}_{4}$ with concentration of $10 \%$ for 24 hours before it was separated from its solution using filtration. Carbon produced from previous step was then washed using ultrasonic cleanser and dried in oven at temperature of $120^{\circ} \mathrm{C}$ for 1 hour. Activated carbon was characterized and tested for its water content, ash content, and methylene blue adsorption capacity using Indonesian Standard Method number 06-3730-1995.

Performance test of activated carbon on adsorption column

Waste cooking oil used in this study as raw material was characterized before it was used for adsorption performance test for its FFA content using Indonesian Standard Method number 01-3555-1998. The FFA content of raw material should not exceed $3 \%$.

Continuous adsorption process of waste cooking oil was performed by flowing it into adsorption column with flow rate of 3,5 , and 7 $\mathrm{ml} / \mathrm{min}$ containing activated carbon with constant amount of 25 grams. After adsorption process was completely done, the waste-cooking oil output sample was obtained and then analyzed for its various characteristics such as FFA content, acid value, and peroxide value to evaluate the performance of activated carbon in continuous adsorption process.

\section{RESULTS AND DISCUSSION}

\section{Activated carbon synthesis from coconut fiber}

From this study, we obtained activated carbon with particle size of 50 mesh and yield of $40 \%$. The characterization of activated carbon produced from in this study is presented in Table 1. Moreover, the functional groups of chemical compounds contained in activated carbon developed in this study were also analysed using Fourier Transform Infrared (FT-IR), as displayed in Fig. 3. This analysis was done for carbon before and after activation process.

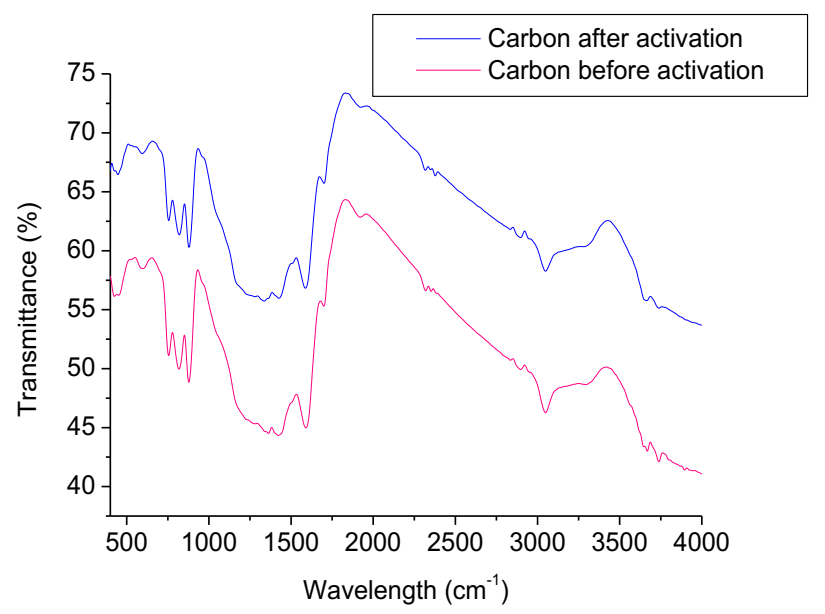

Fig. 3 FTIR spectra of carbon before and after activation.

Table 1 Activated carbon characterization results.

\begin{tabular}{llccc}
\hline No & Parameters & $\begin{array}{c}\text { Carbon before } \\
\text { activation }\end{array}$ & $\begin{array}{c}\text { Carbon after } \\
\text { activation }\end{array}$ & $\begin{array}{c}\text { Standardized } \\
\text { carbon (SNI } \\
\text { No. 06-3730- } \\
1995)\end{array}$ \\
\hline 1 & Water content (\%) & 4.1 & 2.5 & Max. 15 \\
2 & Ash content (\%) & 2.9 & 2.3 & Max. 10 \\
3 & Methylene blue \\
adsorption capacity & 568.4 & 1646.1 & Min. 120 \\
(mg/g) & & & \\
\hline
\end{tabular}


It is obvious from Table 1 that activated carbon produced from this study complied with all parameters stated in Indonesian Standard Method number 06-3730-1995, meaning that activated carbon produced from this study contained high content of cellulose.

As a solid adsorbent, one of important parameters is pore size which can be represented by methylene blue adsorption capacity. This parameter can represent macro pore and mesoporous size of solid adsorbent. Activation process could increase its pore up to 3 (three) times as can be seen from Table 1.

It can be seen from Fig. 3 that activation process developed in this study did not give impact on the change of functional group for carbon before and after activation process. Table 2 summarizes the list of functional groups detected from FTIR analysis. The alkene group (=CH) appeared at the peaks of waves in range of 675-995 and 3010-3095 $\mathrm{cm}-1$, which might be formed by breaking off the molecular structure of water at a temperature of $150-240{ }^{\circ} \mathrm{C}$. The aromatic groups $(\mathrm{C}=\mathrm{C})$ appeared at the wavelength of $690-900 \mathrm{~cm}-1$ and $1500-1600 \mathrm{~cm}-1$ while the aromatic groups $(\mathrm{CH})$ appeared at the wavelength of $690-900$ and $3010-3100 \mathrm{~cm}-1$ might be formed due to aromatization process during carbonization process at temperature of $400-600{ }^{\circ} \mathrm{C}$. While the alkane $(\mathrm{C}-\mathrm{H})$ group appeared at the peak of $3200-3600 \mathrm{~cm}-1$ could be formed by thermal degradation at temperature of $240-400{ }^{\circ} \mathrm{C}$. FTIR analysis results proved that activated carbon produced from this study was non-polar adsorbent having an ability to adsorb free fatty acid due to the presence of non-polar $\mathrm{C}-\mathrm{H}$ functional group. However, this activation process did not change the chemical properties of activated carbon. Activation process only enhanced the physical properties of activated carbon shown by its increasing adsorption capacity on methylene blue.

Table 2 FTIR functional groups analysis of carbon.

\begin{tabular}{|c|c|c|}
\hline Functional Groups & Functional groups name & -Wavelength \\
\hline$=\mathrm{C}-\mathrm{H}$ & Alkene & $-675-995 ; 3010-3095$ \\
\hline $\mathrm{C}-\mathrm{H}$ aromatic & Aromatic & $690-900 ; 3010-3100$ \\
\hline $\mathrm{C}=\mathrm{C}$ aromatic & Aromatic & $1500-1600$ \\
\hline $\mathrm{C}-\mathrm{H}$ & Alkane & $2850-29702850-2970$ \\
\hline & & ; 1340-1470 \\
\hline
\end{tabular}

\section{The effect of waste cooking oil flow rate on continuous adsorption process}

In this study, the adsorption performance of activated carbon in adsorption column was evaluated based on free fatty acid (FFA) reduction. Fig. 4 shows the profile of relationship between FFA reduction and adsorption operating time for various waste cooking oil flow rates.

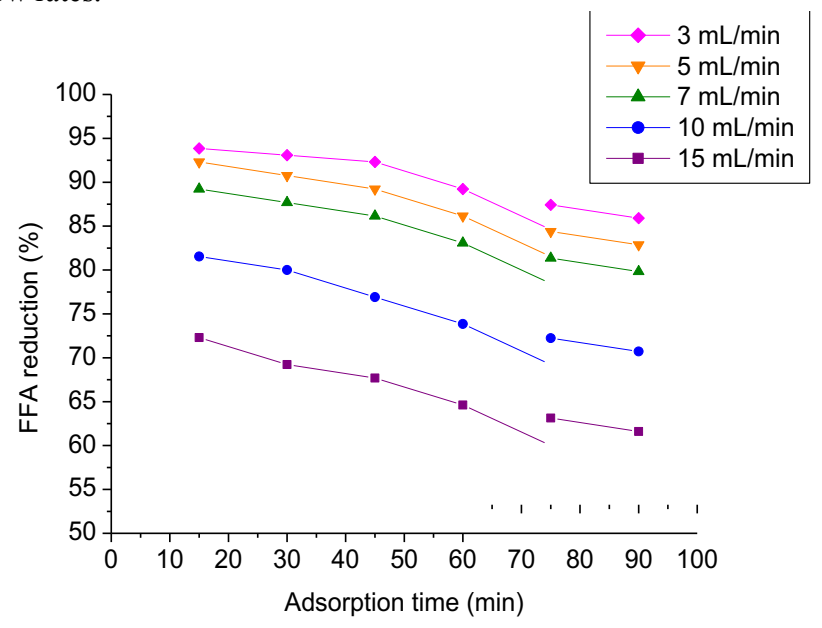

Fig. 4 Relationship between FFA reduction (\%) and adsorption operating time (minute).

Fig. 4 reveals that the longer adsorption operating time, the FFA reduction became lower as well as when waste cooking oil flow rates were raised. This indicated that the adsorption capacity of activated carbon produced in this study was decreased as increasing of adsorption operating time.

Activated carbon produced in this study could achieve FFA reduction of waste cooking oil feed until $93 \%$ at waste cooking oil flow rate of $3 \mathrm{ml} / \mathrm{min}$ for not longer than 45 mins. It meant that with FFA content of $3 \%$ in the feed, this activated carbon could reduce FFA content until $0.3 \%$, which complied with Indonesian standard method number 01-3741-2013 as biodiesel feedstock. However, for this flow rate, the product that could be obtained from this product was $135 \mathrm{ml}$. But for other flow rate variables, they could not achieve $90 \%$ of FFA reduction.

Table 3 Adsorption process product characterization.

\begin{tabular}{|c|c|c|c|c|}
\hline No & Parameters & $\begin{array}{c}\text { Waste } \\
\text { cooking oil } \\
\text { before } \\
\text { adsorption }\end{array}$ & $\begin{array}{c}\text { Waste } \\
\text { cooking oil } \\
\text { after } \\
\text { adsorption } \\
\end{array}$ & $\begin{array}{c}\text { Standardized } \\
\text { cooking oil } \\
\text { (SNI No. 01- } \\
3741-2013 \text { ) } \\
\end{array}$ \\
\hline 1 & $\begin{array}{l}\text { Water content } \\
(\%)\end{array}$ & $3.33 \pm 0.02$ & $0.2 \pm 0.02$ & Max. 0.3 \\
\hline 2 & Density (g/ml) & $\begin{array}{l}0.928 \pm \\
0.005\end{array}$ & $\begin{array}{l}0.876 \pm \\
0.002\end{array}$ & Max. 0.9 \\
\hline $\begin{array}{l}3 \\
4 \\
5\end{array}$ & $\begin{array}{l}\text { Free fatty acid } \\
\text { content }(\%) \\
\text { Acid value } \\
(\mathrm{mgNaOH} / \mathrm{g}) \\
\text { Peroxyde value } \\
(\mathrm{mg} \mathrm{eq} / \mathrm{kg})\end{array}$ & $\begin{array}{l}3.83 \pm 0.03 \\
0.57 \pm 0.00 \\
3.33 \pm 0.02\end{array}$ & $\begin{array}{c}0.294 \pm \\
0.05 \\
0.444 \pm \\
0.011 \\
1.00 \pm 0.02\end{array}$ & $\begin{array}{c}\text { Max. } 0.3 \\
\text { Max. } 2 \\
\text { Max. } 2\end{array}$ \\
\hline
\end{tabular}

Moreover, oil obtained from adsorption product was characterized in terms of several parameters including water content, density, FFA content, acid number, and peroxide number. Table 3 reveals that activated carbon produced from this study has a good ability to reduce those parameters to meet Indonesian standard number 01-3741-2013 requirement as biodiesel feedstock.

\section{CONCLUSION}

This study has successfully synthesized activated carbon from coconut fiber with yield of $40 \%$ and characteristics which complied with Indonesian Standard Number 06-3730-1995 in terms of water content, ash content, and methylene blue adsorption capacity with the value of $2.5 \%, 2.3 \%$ and $1646.1 \mathrm{mg} / \mathrm{g}$ carbon, respectively.

Activated carbon produced in this study was successfully applied for continuous adsorption process to reduce FFA content of waste cooking oil. This activated carbon reduced the FFA content of waste cooking oil up to $93 \%$ for adsorption operating time of 45 minutes and produced waste cooking oil with FFA content of $0.3 \%$ which complied with Indonesian standard method number 01-3741-2013 as biodiesel feedstock.

\section{ACKNOWLEDGEMENT}

Authors would like to gratefully acknowledge all supports received from the Faculty of Engineering University of Brawijaya via research funding through Contract No: 123/UN10.F07/PN/2017, 15 May 2017.

\section{REFERENCES}

Ahmaruzzaman, M., Gupta, V. K. 2011. Rice husk and its ash as low-cost adsorbents in water and wastewater treatment. Ind. Eng. Chem. Res., 50(24), 13589-13613.

Alharbi, O. M. L., Basheer, A. A., Khattab, R. A., Ali, I. 2018. Health and environmental effects of persistent organic pollutants. J. Mol. Liq., 263, $442-453$.

Ali, I., Alothman, Z. A., Alwarthan, A. 2017. Supra molecular mechanism of the removal of 17- $\beta$-estradiol endocrine disturbing pollutant from water on functionalized iron nano particles. J. Mol. Liq., 241, 123-129.

Asfaram, A., Ghaedi, M., Agarwal, S., Tyagi, I., Gupta, V. K. 2015. Removal of basic dye Auramine-O by $\mathrm{ZnS}$ :Cu nanoparticles loaded on activated carbon: optimization of parameters using response surface methodology with central composite design. RSC Adv., 5, $18438-18450$. 
Bonassa, G., Schneider, L. T., Alves, H. J., Meier, T. R. W., Frigo, E. P., \& Teleken, J. G. 2016. Sugarcane bagasse ash for waste cooking oil treatment applications. J. Environ. Chem. Eng. 4(4, Part A), 4091-4099.

Canakçi, M., \& Ozsezen, A. N. 2010. Evaluating waste cooking oils as alternative diesel fuel. Gazi University Journal of Science, 18(1), 81-91.

Cvengroš, J., \& Cvengrošová, Z., 2004. Used frying oils and fats and their utilization in the production of methyl esters of higher fatty acids. Biomass Bioenergy, 27(2), 173-181.

Devaraj, M., Saravanan, R., Deivasigamani, R., Gupta, V. K., Gracia, F., Jayadevan, S. 2016. Fabrication of novel shape $\mathrm{Cu}$ and $\mathrm{Cu} / \mathrm{Cu}_{2} \mathrm{O}$ nanoparticles modified electrode for the determination of dopamine and paracetamol. J. Mol. Liq., 221, 930-941.

Ghaedi, M., Hajjati, S., Mahmudi, Z., Tyagi, I., Agrwal, S., Maity, A., Gupta, V. K. 2015. Modeling of competitive ultrasonic assisted removal of the dyes - Methylene blue and Safranin-O using $\mathrm{Fe}_{3} \mathrm{O}_{4}$ nanoparticles. Chem. Eng. J., 268, 28-37

Gupta, V.K., Jain, R., Nayak, A., Agarwal, S., Shrivastava. 2011. Removal of the hazardous dye-Tartrazine by photodegradation on titanium dioxide surface. Mater. Sci. Eng. C., 31(5), 1062-1067.

Gupta, V. K., Saleh, T. A. 2013. Sorption of pollutants by porous carbon, carbon nanotubes and fullerene- An overview. Environ. Sci. Pollut. R., 20(5) $2828-2843$.

Gupta, V. K., Ali, I., Saleh, T. A., Siddiqui, M. N., Agarwal, S. 2013. Chromium removal from water by activated carbon developed from waste rubber tires. Environ. Sci. Pollut. R., 20(3), 1261-1268.

Gupta, V. K., Nayak, A., Agarwal, S., Tyagi, I. 2014. Potential of activated carbon from waste rubber tire for the adsorption of phenolics: Effect of pretreatment conditions. J Colloids Surface Sci., 417, 420-430.

Gupta, V. K., Atar, N. Yola, M. L., Üstündağ, Z., Uzun, L. 2014. A novel magnetic Fe@Au core-shell nanoparticles anchored graphene oxide recyclable nanocatalyst for the reduction of nitrophenol compounds. Water Res., 48, 210-217.

Khan, T. A., Nazir, M., Ali, I., Kumar, A. 2017. Removal of Chromium(VI) from aqueous solution using guar gum-nano zinc oxide biocomposite adsorbent. Arab. J. Chem., 10, S2388-S2398.

Khani, H., Rofouei, M. K., Arab, P., Gupta, V. K., Vafaei, Z. 2010. Multi-walled carbon nanotubes-ionic liquid-carbon paste electrode as a super selectivity sensor: Application to potentiometric monitoring of mercury ion(II). $J$ Hazard Mater. 183(1-3), 402-409.

Knothe, G., Krahl, J., \& Van Gerpen, J. 2010. The Biodiesel Handbook (Second Edition) (pp. v): AOCS Press.

Kulkarni, M. G., \& Dalai, A. K. 2006. Waste cooking oil-An economical source for biodiesel: A Review. Ind. Eng. Chem. Res., 45(9), 2901-2913.

Marchetti, J. M., Miguel, V. U., \& Errazu, A. F. 2008. Techno-economic study of different alternatives for biodiesel production. Fuel Process. Technol., 89(8), 740-748.

Mittal, A., Mittal, J., Malviya, A., Gupta, V. K. 2010. Removal and recovery of Chrysoidine Y from aqueous solutions by waste materials. J. Colloid Interface Sci., 344(2), 497-507.

Mohammadi, N., Khani, H., Gupta, V. K., Amereh, E., Agarwal, S. 2011. Adsorption process of methyl orange dye onto mesoporous carbon material-kinetic and thermodynamic studies. J. Colloid Interface Sci., 362(2), 457-462.

Phan, N.H., Rio, S., Faur, C., Le Coq, L., Le Cloirec, P., Nguyen, T. H. 2006 Production of fibrous activated carbons from natural cellulose (jute, coconut) fibers for water treatment applications. Carbon, 44(12), 25692577.

Rashidi, N. A., Yusup, S., Loong, L. H. 2013. Kinetic studies on carbon dioxide capture using activated carbon. Chem. Eng. Trans. 35, 361-366.

Rashidi N.A., Yusup S. 2015. Effect of process variables on the production of biomass-based activated carbons for carbon dioxide capture and sequestration. Chem. Eng. Trans., 45, 1507-1512.

Saleh, T.A., Gupta, V. K. 2011. Functionalization of tungsten oxide into MWCNT and its application for sunlight-induced degradation of rhodamine B. J. Colloid Interface Sci., 362(2), 337-344.

Saleh, T. A., Gupta, V. K. 2012. Photo-catalyzed degradation of hazardous dye methyl orange by use of a composite catalyst consisting of multi-walled carbon nanotubes and titanium dioxide. J. Colloid Interface Sci., 371(1), 101-106.

Saleh, T. A., Gupta, V. K. 2014. Processing methods, characteristics and adsorption behavior of tires derived carbons: A review. Adv. Colloid Interface Sci., 211, 92-100

Sanjid, A., Kalam, M. A., Masjuki, H. H., Varman, M., Zulkifli, N. W. B. M., \& Abedin, M. J. 2016, Performance and emission of multi-cylinder diesel engine using biodiesel blends obtained from mixed inedible feedstocks. $J$. Clean. Prod., 112, Part 5, 4114-4122.

Sanjid, A., Masjuki, H. H., Kalam, M. A., Rahman, S. M. A., Abedin, M. J., \& Palash, S. M. 2014. Production of palm and jatropha based biodiesel and investigation of palm-jatropha combined blend properties, performance, exhaust emission and noise in an unmodified diesel engine. J. Clean. Prod., 65, 295-303.

Saravanan, R., Karthikeyan, S., Gupta, V. K., Sekaran, G., Narayanan, V., Stephen, A. 2013a. Enhanced photocatalytic activity of $\mathrm{ZnO} / \mathrm{CuO}$ nanocomposite for the degradation of textile dye on visible light illumination. Mater. Sci. Eng. C., 33(1), 91-98.

Saravanan, R., Thirumal, E. Gupta, V. K., Narayanan, V., Stephen, A. 2013b. The photocatalytic activity of $\mathrm{ZnO}$ prepared by simple thermal decomposition method at various temperatures. J. Mol. Liq., 177, 394-401.

Saravnan, R., Gupta, V. K., Prakash, T., Narayanan, V., Stephen, A. 2013c. Synthesis, characterization and photocatalytic activity of novel $\mathrm{Hg}$ doped $\mathrm{ZnO}$ nanorods prepared by thermal decomposition method. J. Mol. Liq. 178, 88-93.

Saravanan, R., Joicy, S., Gupta, V. K., Narayan, V., Stephen, A. 2013d. Visible light induced degradation of methylene blue using $\mathrm{CeO} 2 / \mathrm{V} 2 \mathrm{O} 5$ and $\mathrm{CeO} 2 / \mathrm{CuO}$ catalysts. Mater. Sci. Eng. C, 33(8), 4725-4731.

Saravanan, R., Karthikeyan, N., Gupta, V. K., Thirumal, E., Thangadurai, P., Narayanan, V., Stephen A. 2013e. ZnO/Ag nanocomposite: An efficient catalyst for degradation studies of textile effluents under visible light. Mater. Sci. Eng. C, 33(4), 2235-2244.

Saravanan, R., Gupta, V. K., Narayanan, V., Stephen, A. 2013f. Comparative study on photocatalytic activity of $\mathrm{ZnO}$ prepared by different methods. $J$. Mol. Liq., 181, 133-141.

Saravanan, R., Gupta, V. K., Narayanan, V., Stephen, A. 2014a. Visible light degradation of textile effluent using novel catalyst $\mathrm{ZnO} / \gamma-\mathrm{Mn}_{2} \mathrm{O}_{3}$. J Taiwan Inst. Chem. E., 45(4), 1910-1917.

Saravanan, R., Gupta, V. K., Mosquera, E., Gracia, F. 2014b. Preparation and characterization of $\mathrm{V}_{2} \mathrm{O}_{5} / \mathrm{ZnO}$ nanocomposite system for photocatalytic application. J. Mol. Liq., 198, 409-412.

Saravanan, R., Khan, M. M., Gupta, V. K., Mosquera, E., Gracia, F., Narayanan, V., Stephen, A. 2015a. $\mathrm{ZnO} / \mathrm{Ag} / \mathrm{CdO}$ nanocomposite for visible lightinduced photocatalytic degradation of industrial textile effluents. J. Colloid Interface Sci., 452, 126-133.

Saravanan, R., Khan, M. M., Gupta, V. K., Mosquera, E., Gracia, F., Narayanan, V., Stephen, A. 2015b. $\mathrm{ZnO} / \mathrm{Ag} / \mathrm{Mn}_{2} \mathrm{O}_{3}$ nanocomposite for visible lightinduced industrial textile effluent degradation, uric acid and ascorbic acid sensing and antimicrobial activity. RSC Adv., 5, 34645-34651.

Saravanan, R., Sacari, E., Gracia, F., Khan, M. M., Mosquera, E., Gupta, V. K. 2016a. Conducting PANI stimulated $\mathrm{ZnO}$ system for visible light photocatalytic degradation of coloured dyes. J. Mol. Liq., 221, 1029-1033.

Saravanan, R., Khan, M. M., Gracia, F., Qin, J., Gupta, V. K., Stephen, A 2016b. $\mathrm{Ce}^{3+}$-ion-induced visible-light photocatalytic degradation and electrochemical activity of $\mathrm{ZnO} / \mathrm{CeO}_{2}$ nanocomposite. Sci. Rep., 6, 3141 .

Seixas F., Goncalves E., Olsen M., Gimenes M.L., Fernandes-Machado N. 2017 Activated carbon from sugarcane bagasse prepared by activation with $\mathrm{CO}_{2}$ and bio oil recuperation, Chem. Eng. Trans., 57, 139-144.

Sonkaew, R., \& Chaisena, A. 2012. Regeneration of used frying palm oil by inorganic adsorbent combinations. Asian J. Chem. 24(2), 677-682.

Suhas, Gupta, V. K., Carrott, P. J. M., Singh, R., Chaudhary, M., \& Kushwaha, S. 2016. Cellulose: A review as natural, modified and activated carbon adsorbent. Bioresour. Technol., 216, 1066-1076.

Ullah, Z., Bustam, M. A., \& Man, Z. 2015. Biodiesel production from waste cooking oil by acidic ionic liquid as a catalyst. Renew. Energ., 77, 521-526. 